\title{
Death and Woman: \\ Comparing the Meaning of the Deaths of the Female Main Characters in the Works of Toni Morrison and Alice Munro
}

\author{
Achmad Munjid* \\ American Studies, Universitas Gadjah Mada, Indonesia \\ *Email: munjid@ugm.ac.id
}

\section{ABSTRACT}

\begin{abstract}
This paper seeks to explore the meaning of death in two important works by two female Noble Prize winning authors, Toni Morrison and Alice Munro. Hagin's (2010) theory of role of death in storyline is used to analyze the works. The three deaths found in the story: initial death, intermediary death and story-terminating death all have significant meaningful relation to the past and the future. They have epistemological value of revealing and/or exposing the truth from the past. Death is used as technical instrument to reveal the truth, to transform ignorance into knowledge, dishonesty into accountability, to purify the past from falsehood and lies. Death also inserts its demand in the story by removing obstacle or giving opportunity for the living to set up new goal. The demand of the dead is possible since the deceased is "remembered" by the "cult" who may follow or manipulate their legacy. The two authors articulate "feminist voice" through the struggle of the main female characters. Toni Morrison articulates the dehumanizing consequence of racism, whereas Alice Munro voices her concern on the contradictory nature of orderly neat appearance of the modern people versus scandalous dark secret beneath the surface.
\end{abstract}

Keywords: dehumanization, feminist voice, initial death, intermediary death, story-terminating death, racism.

\section{INTRODUCTION}

Although death is always individual and personal, as social fact it is also a cultural event filled with layers of collective experience and memory. Therefore, in every culture death is always loaded with all kind of meanings. In her important work, Ariès (1974) argues that the meaning of death in Western society has shifted from time to time. The meaning of death both influence and being influenced by other social aspects such as changes of technology, the notion of "individual", transformation of religious authority, family relationship etc. Different cultural backgrounds, according to Peveto (2004), also contribute to how people perceive death. That is why, understanding about death is always diverse in accordance with cultural, religious, and racial backgrounds (Parkes, 1997). Since the 1970s, especially as pioneered by Kubler-Ross (2008), death and dying have been increasingly popular among American academia and beyond, both as a research interest in a particular field such as anthropology, sociology, psychology, religion, philosophy, history, or law as well as an interdisciplinary research topic. Nevertheless, as Critchley (2004) argues, only within the last two decades, the same interest in death and dying grow significantly in the field of literature. 


\section{LITERATURE REVIEW}

Despite the fact that death has been a central issue in many works of world literature, literary criticism emphasizing on death and dying are not yet equally popular. Several works should be mentioned here. From different points of view, Bevington (1989), Berry (1999) and McMullan (2008) have discussed the significance of death in the works of William Shakespeare. Kabir (2001) investigates the notion of heaven, death and afterlife in Anglo-Saxon literature, whereas Thompson (2004) discusses the issue of death in the Anglo-Saxon English tradition from later period. Representation of death and funeral in English society during the Victorian Age was very well written by Hotz (2009). A very perceptive comparative analysis on the issue of death in the works of Edmund Spenser, a 16th century English poet, and John Milton, a 17th century English poet was written by Bellamy (2004). All of these important works support the argument that the meaning of death is changing over time and through different cultures.

The topic of death also becomes the main focus of several other important works analyzing different authors from later period such as Walt Wiltman, Ernest Hemingway, Arthur Miller, Henry James and others (Snyder, 1982; Napier, 1983; Mandel, 2004; Aspiz, 2005; Cutting, 2006; Ellis, 2008). In particular, Leo Tolstoy's The Death of Ivan Illich has become a focus of interesting interdisciplinary discussions. Bloom (2006, 2009), a professor in Literature at Yale University also wrote important books on death and dying in literature by highlighting central topics on death and dying in well-known English literature across periods.

Focusing on several works by two Noble laureates in literature, Toni Morrison and Alice Munro, this paper investigates how the central theme of death is used in the development of the story. Besides winning Nobel Prizes in literature, arguably the most prestigious award in the field, both authors were chosen in this research for their "feminist voice". Much have been written about them, many of which focus on the two authors' message of "feminism". However, none has given particular interest to relate their analysis to the central message of death. This paper attempts to fill this gap. In particular this paper seeks to answer the following inter-related questions. What is the role of death as central theme in the works investigated? How is the (female) main character affected by death in the story? What is the deeper message behind the meaning of death as "voiced" through those female characters?

\section{THEORETICAL FRAMEWORK}

In answering the research questions, I will use two main theories. First, I will use "typology of death" proposed by Hagin to understand the meaning of death in the structure of the story line. In his important work, Death in Classical Hollywood Cinema (2010), Hagin analyses the significance and meaning of death by identifying how death is positioned in the structure of the story, "how the event of death meaningfully functions in relation to events that come before or after it in a personal linear causal storyline". By using a concept of "narrative" proposed by David Bordwell, he argues that death in a story is to be understood not based on social biases and function. The Hollywood narrative, and by extension also other fictional narrative, is in fact "character centered" and is based upon "causality, consequence, psychological motivations, the drive toward overcoming obstacles and achieving goals". The meaningfulness of death in movie and fiction as a "consructed world" is therefore to be found not in the "how and why" of empirical reality, but in the "how and why" of the storyline. To follow Eagleton (2013), it is unacceptable to treat "created character" of fiction as if they are historical living being. The "how" and the "what" should be simultaneously taken into account in analyzing literary work. It should be noted that "story" here is different from plot. Story is the events in their presumed spatial, temporal, and causal relations, whereas plot is the totality of formal and stylistic materials in the story which may not necessarily be chronological in order. Or, in the words of Abrams (1999, p. 172), "story" is a mere sequence of events put in chronological order, while "plot" is organized and meaningful structure of presenting the story. Furthermore, events in each storyline follow each other in a cause-and-effect logic. Coincidences, natural or social causes, and 
impersonal determinism are not common factors in the narratives (Hagin, 2010, pp. 4-5).

In that relation, Hagin analyses how the event of death meaningfully functions in relation to events that come before and after it in a personal linear causal storyline. Death is meaningful because it is considered as a component of meaningful action, it is the meaning of something that is still taking place, to reveal a becoming, to give a sense to that which is still senseless. Hagin then argues that there are three roles that death can have within a linear causal storyline: a) initial death, which begins a storyline and is a cause of subsequent events; b) intermediary death, which is both an effect and a cause within a storyline; and c) story-terminating death, which ends a storyline and is an effect of previous events.

\section{Hagin further proposes that:}

There are three aspects in which death can be meaningful within such a cause-and-effect chain of events: story-terminating and intermediary deaths can be meaningful in relation to the past, by being results of previous events. Initial and intermediary deaths can be meaningful in relation to the future, by being causes of subsequent events. Death can also remain part of ongoing event with no end in sight, which might be thought of as a type of intermediary death that is meaningful in relation to the present. (Hagin, 2010, p. 5)

According to Hagin, in relation to the past, death can be meaningful by having "epistemological value"; it manifests a truth that is already there; it confirms the truth. The meaningfulness of death in relation to the past is that it reveals, clarifies, and realizes what already existed, at least potentially, in the situation that caused death. Here death is meaningful not by changing what has already happened, but by revealing the truth about it, sometimes by becoming the moment when the painful truth is broken free. Death is seen as "the key to gaining knowledge". Death is turned "into technical instrument that provides a grasp on the truth of life and the nature of its illness". In the words of Walter Benjamin, it is death that gives a person "the unique authority" to tell the truth, to be heard as authoritative source to convey information that remained unknown in the past (Hagin, 2010, pp. 12-18). In that relation, death can change ignorance into knowledge in the form of discovery of new information or the disclosure of a secret. Or, it can be a change in attitude from falsehood to honesty, from self-delusion and childishness to acknowledgement and accountability, from immaturity to maturity, from pretense, avoidance and lack of attention in relation to the truth being exposed in the story to a call for authenticity and genuineness, to be the center of attention (Hagin, 2010, p. 13). The death that happened to a character in the story is not positioned just as an end for his or her life, but as a moment to "purify falsehood of the past". The arrival of death puts an end to games, illusion, lies and allow no more deceptions (Hagin, 2010, p. 18).

In relation to the past, death can also be presented as a momentum to end someone, usually the evil one, who cannot be stopped in any other way. In the storyline, this death happened to what Hagin calls a "killable" character, someone who deserve to be killed due to the fact that he or she is incapable of changing demanded by the progress of the story, someone who is "too stubborn" or has "too much integrity" (Hagin, 2010, pp. 26-28). A reasonable death is death that happens to a character who passed the "killability test" based on the principle of "survival of the fittest" in the storyline.

In relation to the future, initial and intermediary death can be meaningful when it has significant impact but not to the extent that will stop the whole story. "Death must have its sting". It can be in the form of removing the existing obstacle or setting up a new goal for the main character. Death might help the remaining characters to alter their desired goal in life or trigger a direct emotional effect that will set up a new desired goal for them. Or, death can also affect the goals of characters that have not happened yet (Hagin, 2010, pp. 45-51). Death can also be meaningful in the storyline because of how the living remembers the dead and how the demand of the dead affects the living. Death makes a certain character "absent", however his or her "demand", explicitly or implicitly, may be "present" and lead the course of the story. The meaning of death happenning to a character can also be identified through the progress 
of the story by looking at how the reamining characters "remember" the deceased, or more accurately the life of the dead character and how it significantly affects their "future". For the deceased to be remembered, the story should provide the reader with what Hagin calls "cult", a group of people, living characters-they can be family members, friends, neighbors, lovers, etc-that retain the memory of the departed one. So the dead will not simply retreat into an anonymous mass. Only when this "cult" exists, initial or intermediary death will be meaningful in relation to the future. Retaining the memory of the dead is understood in its neutral sense, not necessarily positive. It can be in the form of truth contestation about or related to the dead "in the service of the living" (Hagin, 2010, p. 70). Also, death needs to be meaningful not only by being a cause and/or effect within a linear, individual-driven storyline. It also needs to be "justified" according to other criteria, including devices of narrative cohesion. Eventually, in this paper the aforementioned analysis on the meaning of death was used to identify how the feminist voice is spoken to address gender issues as reflected in the story.

\section{RESULTS AND DISCUSSION}

\section{The Bluest Eye: Multiple Dying Faced by a Little Girl}

The Bluest Eye by Toni Morrison was first published in 1962 as a short story about dehumanizing consequence of racism. Toni Morrison was very much troubled by a classmate of hers, a little black girl, during her elementary school years who wanted to have blue eyes, a wish that reflects both inferiority complex and contempt against her own race. The story was then developed into a novel in 1965 when the civil right movement in the US entered a new decisive historical juncture. However, no publisher wanted the story until it got published in 1970. Just like the main character in the novel, as Toni Morrison wrote in her 1993 publication afterword, the initial publication of The Bluest Eye was dismissed, trivialized, misread. Only slowly the novel was recognized and eventually help its author won the Nobel Prize Award in 1993.
The main character of The Bluest Eye by Toni Morrison is Pecola, an 11 year-old Black girl who was born and raised in an extremely broken family. Living in Lorrain, Ohio, in the early 1940s against the setting of a very racist American society, Pecola experiences multiple oppressions, socially, physically and mentally. Her family is not only economically poor, but also dysfunctional on many levels. Physical violence and verbal abuse is part of the routine in the family. Brutal fights between Cholly and Pauline Breedlove, her parents, take place regularly in front of her eyes. Being drunken most of the time when returning home, Cholly frequently also forced his wife to have sex right next to Pecola. Sammy, Pecola's big brother "run away from home more than twenty seven times". The only people Pecola feels convenient to talk to are three prostitutes who live upstairs, in the same apartment. After another fight, Cholly Breedlove tried to set the house and his family on fire that led him to the jail and caused the entire family homeless. That is how Pecola was introduced to Claudia, the narrator of the story and her family by way of being assigned by the government to live temporarily with them. Death is constantly present in Pecola's life, not only from outside but also inside her own family. From the time Pecola was born, her mother already stamped her as "ugly". At school she was the target of regular mockery. Seeing from her childhood perspective, she thought that her miserable life was resulted from the fact that she has the wrong eyes. She always wanted to make herself disappear when the world is so unbearable, but it is impossible because of her eyes. That's the reason why she was eventually obsessed with blue eyes that, she believed, will make the world around her change. One day in the Spring, her drunken father raped her while she was washing dishes by herself at home and became pregnant. Her baby died and she became insane. Since then, what the ruined Pecola could do is only to talk to her "imaginary" friend about the blue eyes the she got after seeking help from the pedophilic fortuneteller Soaphead Church. In racist patriarchal society as described in the novel, Pecola, a little black girl is a victim of the victim's victim.

There are three deaths in the novel, the death of Cholly Breedlove, the death of Aunt Jimmy and the death of Pecola's baby. Cholly also killed three 
other people, but it can be considered as nonpresent or absent death. I will present below my analysis of these three deaths and their meaning in relation to the position of Pecola as the main character.

Although mentioned in the beginning of the story by Claudia the main narrator of the story (Morrison, 1993, p. 7), in accordance to Hagin's typology of death, Cholly Breedlove's and Pecola's baby's death are considered as story terminating death, while the death of Aunt Jimmy is an intermediary death. Story terminating death and intermediary death can be meaningful when it is related to the past. It brings the reader from ignorance to knowledge (Hagin, 2010, p. 13) about the reality of life around Pecola. The three deaths inform the reader about the desperate struggle of Pecola to survive amid the hostile world full of contrast: the changing seasons that lead to death, instead of bringing her life, contrast between the wonderful family and house of "Dick and Jane" in the text book that Pecola reads in school and her own disintegrated family and messy house, contrast between her experience as a hopeless victim of racism by the white and her idealization of white beauty in the form of blue eyes, contrast between the world full of prejudice and biases around Pecola and her innocence as a child etc.

First, let's talk about the death of Aunt Jimmy, an intermediary death, which can be seen as both the effect and cause in the storyline of the novel. This particular death has a decisive epistemological value of revealing the truth, especially about the kind of early life of Cholly Breedlove. The death of Aunt Jimmy is presented to the reader in the early part of the second half of the novel, when the story is told from the perspective of Cholly. By that time, the reader already got sufficient information about the kind of life where Pecola belong, her situation at home, in the neighborhood and at school, as well as the constant discrimination she experiences in her encounter with almost everybody, including the Black who are economically better like Geraldine and Maurine as well as other poor white immigrant like Mr. Yacobowski. The reader is also well informed about the "normal life" of the Black community in Lorrain, where they mock at each other by using the "white vocabularies" and almost everybody internalizes all white standard for themselves. There violence, prostitution, child molestation, domestic violence, exploitation by the powerful, especially male and the white are all very "normal". The story was also already seen from the perspective of Pauline, Pecola's mother who is fond of being "ideal servant" for the white, a good Christian who is ready to punish Cholly, representation of hopeless sinner, and always sees herself and her people, including her "helplessly ugly" daughter as the loser. The story about Aunt Jimmy shifts the perspective of the story from positioning Cholly as the ultimate antagonist to someone with a "human face". It tells the reader on how and why Cholly become like that.

It was Aunt Jimmy who saved Cholly's life. When Cholly was only four days old, "his mother wrapped him in two blankets and one newspaper and placed him on a junk heap by the railroad" (Morrison, 1993, p. 132). Aunt Jimmy rescued the baby. The young mother run away and nobody heard anything about her since then. Cholly's father? He already ran away as soon as he learned that Cholly's mother got pregnant. Cholly grew up without knowing both the faces and names of his parents with Aunt Jimmy as his only family and protector. From Aunt Jimmy, Cholly learned that for them, especially women, "Everybody in the world was in a position to give them orders. White women said "Do this", white children said "Give me that", white men said "Come here", black men said "lay down" (Morrison, 1993, p. 138).

On Sunday morning in a Spring, Cholly found Aunt Jimmy died in her bed after being sick for a couple of days. When the family members of Aunt Jimmy got together for her funeral and started to talk about the stuff she left, Cholly felt disoriented, disconnected, became a boy with nobody around in the world. Right after the funeral, partly to comfort himself, partly to explore the teenager world, he joined other more experienced boys and girls whose family were still there for the funeral. In the dark bushes after the sunset, for the first time he experienced sex with Darlene. Unfortunately, while they were having sex two white hunters with guns watched them and shed their flashlight on them. Those white men forced them to finish their sex. Terrified and ashamed, Cholly followed the order with no choice. That was the first experience for Cholly to rape and being raped at the same time. 
When they returned from the bush, Cholly was completely disoriented and frightened by all kinds of possibilities that might happen afterward, including the possibility that Darlene might get pregnant. By grabbing out some money Aunt Jimmy left in a place only he and she knew, he left the town. Trying to understand the reason why his father left before his birth, he was heading to a town where his biological father possibly lived in. For what? Just to know what he looked like. He was not even sure whether the name Aunt Jimmy partially remembered and told him before her death was the right name. Even if the name was right, how would he identify him? When he imagined that his biological father was just the larger version of himself, he could not even remember what his own self looked like. "He only knew he was fourteen years old, black and already six feet tall." (Morrison, 1993, p. 154). When eventually he could identify a man he believed was his biological father but failed to identify who himself was, Cholly was rejected right away. From that moment on, Cholly became a completely "free man".

"Dangerously free. Free to feel whatever he felt-fear, guilt, shame, love, grief, piety. Free to be tender or violent, to whistle or weep. Free to sleep in doorways or between the white sheets of a singing woman. Free to take a job, free to leave it. He could go to jail and not feel imprisoned, for he had already seen the furtiveness in the eyes of his jailer, free to say "No, suh", and smile, for he already killed three white men.... He was free to live his fantasies, and free even to die, the how and the when of which held no interest for him. In those days, Cholly was truly free. Abandoned in a junk heap by his mother, rejected for a crap game by his father, there was nothing more to lose." (Morrison 1993, pp. 159-160).

His personal biography informed how Cholly has become a complete loser since his teenager. The readers have access to this knowledge through the death of Aunt Jimmy. The death of Aunt Jimmy is therefore a technical instrument to reveal the truth about Cholly's world and its violent nature. The death of Aunt Jimmy has significant impact on Cholly's life. It has the "sting", becomes an obstacle for Cholly for a while, but it then also forces him to set up a new goal in his life without her. When Cholly eventually met Pauline with her broken foot, married her and had children with her, nothing really changed him. "Nothing, nothing, interested him now. Not himself, not other people. Only in drink was there some break, some floodlight, and when that closed, there was oblivion." (Morrison, 1993, p. 160). How he reacted to whatever around him "were based on what he felt at the moment" (p. 161), That's how he raped his own daughter when the drunken Cholly saw Pecola just by herself washing dishes in the kitchen (pp. 161-163).

The departure of Aunt Jimmy unchained Cholly's attachment to the only people that gave him reasonable attention, love, at least meaningful relation as an individual. After her death, Cholly was turned into completely free individual, with an animal-like life. When the narrator Claudia informed the reader toward the end of the novel that Cholly eventually died in the workhouse for unexplained reason, his death was somewhat expected. As a character, Cholly has a very powerful "killability" to use the term by Hagin (2010). With all his characteristics, Cholly is someone who "deserve" to die in order for the story to go on. The death of Aunt Jimmy has led to the death of Cholly. The death of Cholly is in turn related to the death of Pecola's baby. Being only 11 years old and insane, Pecola was pregnant with a baby that is also "killable". Pecola herself is now mentally dying. Suffering from unbearable multiple opressions, she was torn apart.

The intermediary death of Aunt Jimmy and the story-terminating death of Cholly and the baby did not change what has happened to Pecola and her world. They reveal the truth behind it. They explain how things become as such: how and why people hate each other so much, how and why all kind of exploitations and abuse took place, how and why the weakest among the weak like Pecola suffered unbearable reality. She survived but perhaps only for other than herself. So unbearable the reality is for her that Pecola even cannot tell her own story. Other narrator, Claudia, should do it for her. "All of us-all who knew her-felt so wholesome after we cleaned ourselves on her. We were so beautiful when we stood astride her ugliness. Her simplicity decorated us, her guilt sanctified us, her pain made us glow with health, her awkwardness made us think we had a sense of 
humor. Her inaraticulateness made us believe we were eloquent. Her poverty kept us generous. Even her waking dreams we used-to silence our own nightmares." (Morrison 1993, p. 205).

Since Pecola is now carzy, mentally broken, the death of both Cholly and her premature baby has no more significance to her further story. They do not change anything about her afterward. However, again, they explain, reveal, verify the truth of Pecola's story as the weakest innocent victim of a racist world. Through the story of Pecola in the framework of the aforementioned deaths, Toni Morrison powerfully demonstrate how brutally dehumanizing effect of racism is to both the oppressed and the oppressor at the same time.

\section{The Love of a Good Woman: Death, Secret, Lies for a "Habitable" World}

The Love of a Good Woman was published in 1998 in a collection of short stories with the same title. It is among Alice Munro's excellent stories that brought her to the global stage of modern short story writers before she eventually won the Nobel Prize award in 2013. Basically, the story is about the contradictory face of modern people who look very well structured, orderly and nice on the surface but hide many dark and dirty scandals underneath. The main character of the story is Enid, an unmarried 36 years old home nurse who lived in suburban Canada. She grew up as an undetermined but a hardworking individual with a kind of missionary faith. While finishing her nurse's training, her dying father asked her to make a promise: not to work as a nurse. After getting clarification from her mother that behind that request actually her father wanted her to get married, she reluctantly made the promise. Her father was worried that by being a nurse, Enid will be too familiar with men's bodies, sick bodies, that will change her as a girl, making her coarse, and the way men thought about her as a girl. After her father died, she did various jobs, but ended up doing home nurse due to the high demand of that job after the war. She was still single and had no boy friend until then. She got her mother support that doing the home nurse was not necessarily a violation of her promise, because what she promised to her father was not to become a professional nurse at the hospital.
Eventually she was taking care of Mrs. Quinn, a 27 years old housewife who was terminally ill due to kidney failure. Being frustrated by her condition, Mrs. Quinn was very aggressive in her words and behavior. Enid who got used to ill behavior of the patients never took Mrs. Quinn seriously. However, one day Mrs. Quinn told her that Dr. Willens, an eye doctor whose dead body was found drowned in the lake many years ago, was actually killed by Rupert Quinn, her own husband in the room where she laid down today. There was love affair between the doctor and Mrs. Quinn as a long-time patient. They liked to have sex after the eye exam was done. One day Rupert sneakily returned home from his farm when he saw the doctor's car. He caught them and attacked the doctor that fatally killed the later. No body knew about the murder until today. Enid was very much troubled by the story since everything sounded so consistent. In the meantime, her relation with Rupert Quinn who actually was her classmate in high school has now grown closer. Finally Mrs. Quinn died, partly because her time has come, partly because Enid didn't give her the medicine in accordance with the regular schedule. Instead, during that critical time Enid chose to talk with Mrs. Quinn's children outside whether people who did great crime should be punished even when no body knows about what they did. Sometime after Mrs. Quinn died, Enid came back to visit Rupert. She asked him to take her to the middle of the river near the jungle by boat. There she wanted to find out the truth about Mrs. Quinn's story if she has the courage to ask the question in the end.

There are also three deaths found in The Love of a Good Woman: the initial death of Dr. Willen, the intermediary death of Enid's father, and storyterminating death of Mrs. Quinn. The Love of a Good Woman was opened by information about a red box of tools belong to an optometrist named Dr. Willens displayed in a local museum. Soon, the reader is informed that Dr. Willen died in 1951 for unexplained reason and his dead body was found by three teenagers in a Jutland Lake. After giving a vivid life of the setting and how people interact with each other normally there, Alice Munro attracts the reader's attention to a dying woman named Mrs. Quinn.

Mrs. Quinn suffered from "glomerulonephritis". Basically "her kidneys were failing and 
nothing could be done about it" (Munro, 1998, p. 29). The doctor already informed Enid about this terminal illness. "This'll take you into the summer, but the chances are you'll get some kind of a holiday before the hot wheather's over." (p. 29). It means Mrs. Quinn will die very soon according to the doctor's medical calculation. Being terminally ill, Mrs. Quinn's attitude and words are very aggressive. According to Elizabet Kubler-Rose who did intensive research on terminal ill patients, this is a general phenomenon. Terminal ill patients usually go through what Kubler-Rose calls as the five stages of dying: denial, anger, bargaining, depression and acceptance. Mrs. Quinn always speak with her sharp tongue on almost everything and everyone. Perhaps, due to her behavior or something else, her husband, Rupert Quinn and their children were unenthusiastic and discouraged to see her often. Clearly, it was Enid, the nurse who had to be with Mrs. Quinn a lot and get use to her bad temper.

About her husband, for instance, Mrs. Quinn said "Doesn't hang around here very long, does he?" Mrs. Quinn would say. "Makes me laugh. Ha-ha-ha, how-are-you? Ha-ha-ha, off-we-go. Why don't we take her out and throw her on the manure pile? Why don't we just dump her out like a dead cat? That's what he's thinking. Isn't he?" (p. 32). Being a nurse for while and familiar with how some desperate patients behave, Enid never took her words seriously. She did her job normally, changed Mrs. Quinn's cloth, smoothed back her hair from her face, slid a towel under her hips and so on. As if wanted to provoke Enid further, Mrs. Quinn sharpened her tounge again, "“Swole up like some kind of pig," Mrs. Quinn said. "Except for my tits, and they always were kind of useless. I never had no big udders on me, like you. Don't you get sick of the sight of me? Won't you be glad when I'm dead?" Even when Enid tried to neutralize her mood, Mrs. Quinn continued "Good riddance to bad rubbish," said Mrs. Quinn. "That's what you'll all say. Good riddance to bad rubbish. I'm no use to him anymore, am I? I'm no use to any man. He goes out of here every night and he goes to pick up women, doesn't he?" Perhaps of jealousy, perhaps of frustration, perhaps because of self-hatred, she kept on insulting people and provoked others anger to confirm her own dark perception on everything. The haunting death seemed to have led Mrs. Quinn from anger to depression and she desperately push other people to her direction.

The dying Mrs. Quinn plays a very important role in the development of the story. Not only that her death reveals the secret, at least for Enid, but the death also gives Mrs. Quinn "unique authority" about the truth (of Dr. Willens' death, as well as about the nature of social relationship in their society). Initially Enid just ignored Mrs. Quinn's story and treated her much like any other angry serious ill patient. However, the dying condition eventually catch Enid's attention to reconsider and eventually "trust" Mrs. Quinn as the source of authority. Death in this case also shifted pretense, dishonesty, lies into accountability, honesty and genuineness. Under the shadow of death, Mrs. Quinn purify falsehood of the past, by exposing the real story.

Enid's relationship with the dying Mrs. Quinn is closely related to her promise mentioned earlier. It is exactly because Enid didn't really keep her promise that she has to face the problem with the troubled patient, Mrs. Quinn. However, it will be very hard for Enid to keep the promise, literally or not. First, she love working as nurse--she was finishing her training when asked to make the promise. Second, she didn't really understand her father when asked to make the promise. It was her mother who convinced her both when she made the promise and when she broke it. This tells about her undetermined character as a person. The intermediary death of Enid's father, who prohibited the daughter to be a nurse, initially means removal of obstacle for Enid. However, the deceased father's demand is not easily ignored by the daughter. Only after many years have passed does Enid have the courage to "break" her promise to her father and became a home nurse. The death of Enid's father is meaningful in relation to the future, not only because his demand is still there until long time after his absence, but also it plays "epistemological value" by revealing the true character of Enid as indicisive person. Her indicisiveness is even somewhat positioned as legitimate for people who live in modern society where lies are hidden all around. Enid remembered how one day, as a little girl, she was so troubled finding her father acting strengely with an unknown bere breast women in his office room. When she informed this to her 
mother, the immediate response was outright rejection. Enid should withold the truth she herself saw because, being a little girl, she had no authority to interfere with the adult life. Later on, she learned that not every truth, including the truth about her father in the past, should be revealed or known in order to make this world "habitable".

In the meantime, the terminating death of Mrs. Quinn is closely related to the initial death of Dr. Willens, the second reveals the secret of the first. Although Dr. Willen is dead from the beginning, his "presence" is felt throughout the story. He is rememberd by his "cult", people who make his past life has "meaning" without whom he will be forgotten forever. This is not because his demand directly "dictate" the living, like in the case of Enid's father, but his death is being contested, fabricated, manipulated for the sake of the living, especially Rupert and Mrs. Quinn. Even when Mrs. Quinn finally also died, Enid was not very sure whether it is necessary to reveal the truth. For what? Will the revealed truth make the world better or, on the contrary, worse?In that relation, the story-terminating death of Mrs. Quinn reveals not only about the death of Dr. Willens, but also who he is, who Mrs. Quinn is, who Rupert is and even who actually Enid as the main character is. From the causal relationship in the story, it can be concluded that Dr. Willens is a womanizer, Mrs. Quinn is an easy and jealous woman, Rupert is a murderer and Enid is undetermined person. Even the conclusion of the story tells a lot about her character.

Through the lens of a female eye, Enid, as the main character, Alice Munro effectively articulate her message on how woman became powerless subject among the contradictory character of modern people who look nice and orderly on the surface but hide dark even dirty secrets underneath. Enid's character and role in the story in relation the death of her father, the death of Mrs. Quinn and the death of Dr. Willens potrayed all these and everything is reflected very well in the open ending of the story with all kind of possibilities. When the indecisive Enid confronts Rupert about what actually happened to Dr. Willens as indicated by the ending of the story, perhaps he will be shocked, reject her and kill her in the middle of the river. Perhaps, Rupert will admit the truth. After that, perhaps Enid will call the police and faithfully visit him before eventually marry him after his release from the jail. Perhaps, Enid never has the courage to ask the question.

\section{CONCLUSION}

Death is very central in both The Bluest Eye and The Love of a Good Woman. Initial death, intermediary death and story-terminating death that are found in both works has epistemological value in relation to the past and the future. Although those deaths did not change what has happened, it reveals the truth behind it. That is the truth on the dehumanizing effect of racism in The Bluest Eye and the truth about contradictory nature of modern people in The Love of a Good Woman: neatly packaged appearance on the surface but full with dark and dirty scandals inside. The female authors of both works excellently present these deeper messages through the struggle of the main female characters in the story.

\section{REFERENCES}

Abram, M.H. (1999). A glossary of literary terms (7th ed.). New York: Heinle \& Heinle.

Ariès, P. (1974). Western attitudes toward death from the middle ages to the present. London: Johns Hopkins University Press.

Aspiz, H. (2005). So long! Walt Whitman's poetry of death. Tuscaloosa \& London: The University of Alabama Press.

Bellamy, E. (ed.). (2004). Imagining death in Spenser and Milton. New York: Palgrave MacMillan.

Berry, P. (1999). Shakespeare's feminine endings, disfiguring death in the tragedies. London \& New York: Routledge.

Bevington, D. (1989). Is this the promised end, death and dying in King Lear. Proceedings of the American philosophical society, 133(3), 404-415. 
10 | LEXICON, Volume 6, Number 1, April 2019

Bloom, H. (ed.) (2006). Arthur Miller's death of a salesman. New York: Chelsea House Publishers.

Bloom, H. (ed). (2009). Bloom's literary theme: Death and dying. New York: Bloom's Literary Criticism.

Cavitch, M. (2007). American elegy, the poetry of mourning from the puritans to Whitman. Minneapolis: University of Minnesota Press.

Critchley, S. (2004). Almost nothing: Death, philosophy and literature. New York: Routledge.

Cutting, A. (2006). Death in Henry James. New York: Palgrave MacMillan.

Eagleton, T. (2013). How to read literature. New Haven: Yale University Press.

Ellis, D. (2008). Death and the author: How D. H. Lawrence died and was remembered. Oxford \& New York: Oxford University Press.

Hagin, B. (2010). Death in the classical Hollywood cinema. New York: Verso.

Hotz, M. E. (2009). Literary remains, representations of death and burial in Victorian England. Albany, NY: State University of New York Press.

Kabir, A. J. (2001). Paradise, death and doomsday in Anglo-Saxon literature. Cambridge: Cambridge University Press.

Kubler-Ross, E. (2008). On death and dying: What the dying have to teach doctors, nurses, clergies and their own families ( $40^{\text {th }}$ ed.). New York: Routledge.
Mandel, M. (2004). A companion to Hemingway's Death in the Afternoon. Rochester, NY: Camden House

McMullan, G. (2008). Shakespeare and the idea of late writing: Authorship in the proximity of death. Cambridge: Cambridge University Press.

Morrison, T.(1994). The bluest eye. New York: A Plume Book.

Munro, A. (1998). The love of a good woman. Toronto: Douglas Gibson Book.

Napier, J. (1983). The stages of dying and the death of Ivan Ilych. College Literature, 10(2), 147157.

Parkes, C. (1997). Death and bereavement across cultures. London \& New York: Routledge.

Peveto, C. (ed). (2004). Cultural changes in attitudes toward death, dying, and bereavement. New York: Springer Publishing Company.

Smith, R. R. (2010). Death-drive, Freudian hauntings in literature and art. Edinburgh: Edinburgh University Press, Ltd.

Snyder, S. (1982). King Lear and the psychology of dying. Shakespeare Quarterly, 33(4), 449-460.

Thompson, V. (2004). Dying and death in later Anglo-Saxon England. Woodbridge, England: The Boydell Press. 